\title{
Use of Invasive Green Crab Carcinus maenas for Production of a Fermented Condiment
}

\author{
Delaney M. Greiner, Denise I. Skonberg, Lewis B. Perkins and Jennifer J. Perry *(D)
}

Citation: Greiner, D.M.; Skonberg, D.I.; Perkins, L.B.; Perry, J.J. Use of Invasive Green Crab Carcinus maenas for Production of a Fermented Condiment. Foods 2021, 10, 659. https://doi.org/10.3390/ foods10040659

Academic Editors: Marios Mataragas and Loulouda Bosnea

Received: 5 February 2021

Accepted: 16 March 2021

Published: 24 March 2021

Publisher's Note: MDPI stays neutral with regard to jurisdictional claims in published maps and institutional affiliations.

Copyright: (c) 2021 by the authors. Licensee MDPI, Basel, Switzerland. This article is an open access article distributed under the terms and conditions of the Creative Commons Attribution (CC BY) license (https:// creativecommons.org/licenses/by/ $4.0 /)$.
School of Food and Agriculture, The University of Maine, Orono, ME 04469, USA; delaney.greiner@maine.edu (D.M.G.); denise.skonberg@maine.edu (D.I.S.); lewis.perkins@maine.edu (L.B.P.) * Correspondence: jennifer.perry@maine.edu; Tel.: +1-207-581-2940

Abstract: To control the population of an invasive species of green crab, we investigated the feasibility of producing a fermented crab condiment. Commercial fermented fish condiments were tested to assess variability in the marketplace and to identify targets for lab-fermented sauces. Finely chopped crab was combined with $100 \mathrm{mg} \mathrm{g}^{-1}, 200 \mathrm{mg} \mathrm{g}^{-1}$, or $300 \mathrm{mg} \mathrm{g}^{-1} \mathrm{NaCl}$, and spontaneously fermented for up to 120 days. Chromatographic analysis revealed that histamine content was not a safety concern as all treatments were below the current U.S. legal threshold (50 mg $100 \mathrm{~mL}^{-1}$ ). The majority of microbial and physicochemical properties measured within salt level (proteolytic bacterial population, total volatile basic nitrogen (TVBN), amine nitrogen, water activity, moisture, and biogenic amines) were statistically unchanged between days 60 and 120 of fermentation, suggesting that most of the biochemical changes happened early in the fermentation. While the production of a fermented condiment was successful and could represent an opportunity for the valorization of this invasive species, additional work is needed to accelerate the process and further understand the dynamics of the early fermentation stages.

Keywords: Carcinus maenas; histamine; fermentation; fish sauce; green crab

\section{Introduction}

The European green crab (Carcinus maenas) is an extremely aggressive invasive species established on North America's east and west coasts [1,2]. The green crab preys on commercially relevant clam and mussel species, which has adversely affected coastal regions ecologically and economically. This predation has decreased soft-shelled clam populations on the east coast of the United States by $40 \%$, representing a loss of $\$ 22.6$ million per year in sales [2]. Adverse effects of this invasive species are not limited to predation. Mature and juvenile green crabs damage important ecosystems by eating eelgrass and digging through the sediment surrounding eelgrass [3]. These eelgrass beds are a critical habitat, serving as nurseries for juvenile fish, providing protection from native predators, and acting as an essential food resource for diverse species including waterfowl [4]. The presence of green crabs also poses a threat to the American lobster population through competition over prey [5].

Unfortunately, hard shelled green crabs are difficult to use in the culinary industry because of difficulties removing meat from this diminutive species. One opportunity to control this species that has been investigated is the establishment of a soft-shell fishery. This fishery could help exert local control over the population of green crab and is considered low barrier to entry due to the use of existing fishing materials and the lack of trapping limits on this species [1]. In Italy, there are mature soft-shell green crabs selling for as much as $€ 51.14 \mathrm{~kg}^{-1}$, or about $\$ 27 \mathrm{USD} \mathrm{lb}^{-1}$ [1]. Other current uses for the crabs include composting and bait [6], but the establishment of a soft-shelled industry represents the highest value opportunity for fishers.

Pre-molt green crabs are easily identified and can be stored live until suitable for sale in a soft-shell market. However, a significant portion of the trapped crabs are not suitable 
for live storage. Although this excess biomass could be sold as bait or composted, the establishment of an edible use for the excess material would command a higher price for fishers. This additional valorization of excess biomass further incentivizes fishers and makes the system more sustainable [7].

Fermented fish sauce is a clear liquid, brown in color, with a distinct fish flavor [8], which, in its simplest form, consists of the liquid resulting from the spontaneous fermentation of salted whole anchovies and other fish species [9]. The fermentation of a fish sauce typically ranges between 6 and 18 months $[8,10]$, though duration depends on ambient temperature and local preferences. Fermented seafood sauce is historically a widely used condiment in a large number of cultures, particularly those with Asian influence, and is becoming more common in American kitchens [11].

Anchovies are commonly used in fish sauce manufacture because of their low value and abundance of protein, with the Peruvian anchovy having up to $20 \%$ protein [12]. Although anchovies are the most commonly used substrate, diverse species including tilapia, sardines, silver barb fish, and freshwater crab have been used in fermented condiment production [13-17]. Carcinus maenas has a protein content of about $17 \%$ [18], which could be fermented as a way to utilize this valuable protein in the culinary industry without the need to separate the shell and meat. Additionally, this process is relatively low input with little capital investment needed, making this product accessible for small-scale processing operations or cottage producers. The purpose of this work was to assess the physicochemical properties of existing commercial fish sauce products to establish baseline values for a novel, fermented seafood condiment, and to assess the feasibility of using whole green crab as the substrate for such a product.

\section{Materials and Methods}

\subsection{Preparation of Crab}

Green crabs were trapped off the coast of Georgetown, Maine, and transported on ice to the University of Maine (Orono, ME, USA). Live crabs were blast frozen (Southeast Cooler, Lithia Springs, CA, USA) for $1 \mathrm{~h}$ at $-30{ }^{\circ} \mathrm{C}$, then stored at $-20^{\circ} \mathrm{C}$ until use. Frozen whole crabs were thawed for $36-48 \mathrm{~h}$ at $4{ }^{\circ} \mathrm{C}$ before being finely chopped in a Kolsch bowl cutter (UltraSource, Kansas City, MO, USA) and combined with uniodized Kosher salt (Morton Salt, Chicago, IL, USA) at $100 \mathrm{mg} \mathrm{g}^{-1}, 200 \mathrm{mg} \mathrm{g}^{-1}$, or $300 \mathrm{mg} \mathrm{g}^{-1}(w / w)$. All treatments were prepared separately, in triplicate, and packed into clean, $0.95 \mathrm{~L}$ canning jars covered with a double layer of cheesecloth (Pyrm Consumer USA, Spartanburg, SC, USA).

\subsection{Fermentation and Sampling}

Treatments were incubated at $24{ }^{\circ} \mathrm{C}$ for 120 days with intermittent sampling occurring at 60,90 , and 120 days. On each sampling occasion one entire jar from each treatment replicate was utilized (no repeated sampling). The sauce was separated from the solid residue for testing by straining through two layers of non-sterile cheesecloth into $250 \mathrm{~mL}$ centrifuge tubes. The filtrate was centrifuged in an Avanti J-E Beckman Coulter centrifuge (Brea, CA, USA) $(100 \times g, 10 \mathrm{~min})$, and the supernatant was collected for microbial and physicochemical testing.

\subsection{Determination of Microbial Activity}

Crab sauce was serially diluted in $1 \mathrm{~g} \mathrm{~L}^{-1}$ peptone (Becton, Dickinson, and Co., Sparks, MD, USA) and spread plated in duplicate on skim milk agar (SMA), which consisted of brain heart infusion agar (Hardy Diagnostics, Santa Maria, CA, USA). It was supplemented with $100 \mathrm{~mL} \mathrm{~L}^{-1}(v / v)$ aseptically packaged skim milk (Natrel, Quebec, Canada) and $30 \mathrm{mg} \mathrm{g}^{-1}$ salt (Aqua Solutions, Deer Park, TX, USA; incubated at $37^{\circ} \mathrm{C}$ for $48 \mathrm{~h}$ ) to identify proteolytic bacteria [19]. The brain heart infusion agar was supplemented with $30 \mathrm{mg} \mathrm{g}^{-1}$ salt (incubated at $37{ }^{\circ} \mathrm{C}$ for $48 \mathrm{~h}$ ) for total plate count (TPC), and potato dextrose agar (APDA; Alpha Biosciences, Baltimore, MD, USA) was acidified with $0.1 \mathrm{M}$ tartaric acid (Alfa Aesar, Ward Hill, MA, USA; incubated at ambient temperature for 5 day) to isolate 
fungi. All plates were counted with colony density between 30 and 300, and the microbial population was expressed as $\log \mathrm{CFU} \mathrm{g} \mathrm{g}^{-1}$.

\subsection{Determination of Total Volatile Basic Nitrogen (TVBN) and Amine Nitrogen}

Total volatile basic nitrogen was measured [20] via direct distillation with sodium hydroxide. Lab fermented crab sauce sample was homogenized with trichloroacetic acid (Sigma-Aldrich, St. Louis, MO, USA) and centrifuged (1312× g $20 \mathrm{~min})$. The supernatant was distilled in a micro-Kjeldahl apparatus (Labconco, Kansas City, MO, USA) with sodium hydroxide (Fisher Chemical, Fair Lawn, NJ, USA) and antifoaming agent A (Sigma Aldrich, St. Louis, MO, USA). The distillate was collected in boric acid solution (JT Baker, Center Valley, PA, USA) containing methyl-red (Fisher Scientific, Waltham, MA, USA), a methyleneblue (Sigma Aldrich, St. Louis, MO, USA) indicator, and titrated for a color change with $0.1 \mathrm{~N}$ hydrochloric acid (Fisher Scientific, Waltham, MA, USA). TVBN content was expressed as $\mathrm{mg} 100 \mathrm{~mL}^{-1}$.

Proteolytic activity drives increased amine nitrogen content [21]. This measurement is typically used to determine the degree of proteolysis due to activity of endogenous and microbial proteases and can be used to estimate the progress of fermentation. The amine nitrogen was determined using a formol titration published by [22], with the following slight modifications. A concentration of $0.1 \mathrm{~N}$ sodium hydroxide $(\mathrm{NaOH})$ was used for the neutralization of the original sample and formaldehyde. Moreover, $8 \mathrm{~mL}$ of formaldehyde was added (Fisher Scientific, Waltham, MA, USA). The titrant used for the mixture of neutralized formaldehyde and neutralized crab sauce sample was $0.05 \mathrm{~N} \mathrm{NaOH}$. Data were expressed as $\mathrm{mgN} 100 \mathrm{~mL}^{-1}$.

\subsection{Determination of $\mathrm{pH}$, Water Activity, and Moisture Content}

The $\mathrm{pH}$ (Orion Star A111 pH meter, Thermo Scientific, Waltham, MA, USA) was determined through a single, direct reading from each sample. The probe was first calibrated with $\mathrm{pH} 4,7$, and 10 standards. The water activity values (Aqualab, Pullman, WA, USA) were determined through two direct readings and averaged. The water activity meter was first calibrated with a 0.76 calibration standard. Moisture content (\%) was determined using AOAC Method 934.01 [23] at a vacuum of 20 in $\mathrm{Hg}$.

\subsection{Determination of Non-Enzymatic Browning}

Non-enzymatic browning was measured according to the method of [24] with slight modification. One $\mathrm{mL}$ of sauce was stirred using a magnetic stir bar and plate with $10 \mathrm{~mL}$ of ethanol (500 $\mathrm{mL} \mathrm{L} \mathrm{L}^{-1} v / v$ Fisher Scientific, Waltham, MA, USA) for one hour. The mixture was then filtered through a $0.45 \mu \mathrm{m}$ syringe filter (MDI Membrane, Harrisburg, PA, USA) and subjected to an absorbance measurement at $420 \mathrm{~nm}$ with a DU 530 spectrophotometer (Beckman Coulter, Brea, CA, USA).

\subsection{Determination of Biogenic Amine Content}

Biogenic amines in samples and analytical standards were determined using high performance liquid chromatography (HPLC) and the Waters AccQ-Fluor ${ }^{\mathrm{TM}}$ fluorescent tagging system (Milford, MA, USA), a method developed for the determination of amine compounds in foods. The Agilent model 1100/1200 HPLC system included a quaternary pump, autosampler, column heater, fluorescence detector, and Chemstation ${ }^{\mathrm{TM}}$ software. Approximately $1 \mathrm{~mL}$ of crap sauce was filtered through a $0.45 \mu \mathrm{M}$ nylon syringe filter (Cole-Palmer, Vernon Hills, IL, USA). Ten $\mu \mathrm{L}$ of sample filtrates and $10 \mu \mathrm{L}$ of standards were prepared for HPLC analysis with the AccQ. Fluor ${ }^{\text {TM }}$ kit and assayed using the HPLC column and eluents supplied with the kit. All procedures included in the kit directions insert were followed, with a slight modification of the HPLC gradient elution. Standard curves were constructed using five concentrations of histamine, agmatine, putrescine, cadaverine, and tyramine (all from Sigma-Aldrich, St. Louis, MO, USA), ranging from $0.557-0.894 \mathrm{mg} \mathrm{mL}^{-1}$ and diluted with HPLC-grade water. Baseline separation of the 
target analytes was achieved and biogenic amines were identified by comparing retention times from samples with the analytical standards. Peak areas were used to calculate analyte concentrations. Data were expressed as $\mathrm{mg} 100 \mathrm{~mL}^{-1}$.

\subsection{Commercial Fish Sauces}

In addition to laboratory-fermented crab sauce, 12 varieties of commercial fish sauce were obtained from local and online retail outlets. These sauces were subjected to the same analyses described above to create a standard for comparison since fermented crab sauce is not commercially available. Commercial sauces were separated into two tiers (Table 1) according to ingredients (Tier 1 comprised of minimal ingredients suggesting traditionally fermented, higher value product, Tier 2 comprised of sauces containing additional ingredients such as colorants and preservatives) and were compared to each other statistically to identify significant differences. Tier 1 samples, on the basis of higher quality, were identified as better targets for laboratory-fermented sauce and were subsequently compared statistically to day 120 prototypes.

Table 1. Commercial fish sauce physicochemical characteristics.

\begin{tabular}{|c|c|c|}
\hline & $\operatorname{Tier} 1^{a}(n=5)$ & Tier $2^{b}(n=7)$ \\
\hline Ingredients $^{c}$ & $\begin{array}{c}\text { anchovy fish, sea salt, } \\
\text { sugar, water }\end{array}$ & $\begin{array}{l}\text { anchovy extract, water, salt, mackerel } \\
\text { extract, potassium sorbate, fermented } \\
\text { scad fish extract, caramel color, } \\
\text { syrup, sugar }\end{array}$ \\
\hline $\mathrm{pH}$ & $5.56 \pm 0.29$ & $5.41 \pm 0.58$ \\
\hline Water Activity & $0.739 \pm 0.014 *$ & $0.774 \pm 0.027 *$ \\
\hline TVBN (mgN $\left.100 \mathrm{~mL}^{-1}\right)$ & $390.5 \pm 129.4 *$ & $138.3 \pm 141.9 *$ \\
\hline AmineN (mgN $\left.100 \mathrm{~mL}^{-1}\right)$ & $1271.2 \pm 528.8 *$ & $449.0 \pm 447.8 *$ \\
\hline Moisture (\%) & $59.3 \pm 4.1$ & $65.9 \pm 6.8$ \\
\hline Browning & $0.53 \pm 0.24$ & $0.29 \pm 0.29$ \\
\hline Histamine (mg $\left.100 \mathrm{~mL}^{-1}\right)$ & $3.49 \pm 1.69$ & $1.82 \pm 0.61$ \\
\hline Putrescine (mg $\left.100 \mathrm{~mL}^{-1}\right)$ & $3.93 \pm 2.84$ & $3.50 \pm 3.62$ \\
\hline Cadaverine $\left(\mathrm{mg} 100 \mathrm{~mL}^{-1}\right)$ & $0.81 \pm 0.24$ & $0.75 \pm 0.42$ \\
\hline Tyramine (mg $100 \mathrm{~mL}^{-1}$ ) & $2.09 \pm 0.41$ & $1.46 \pm 0.81$ \\
\hline
\end{tabular}

Data are expressed as mean \pm standard deviation. ${ }^{*}$ indicates significant differences in mean values between tiers. ${ }^{a}$ Includes the following brands: A Taste of Thai, Four Elephants, Son Sauce, Red Boat, Golden Boy. ${ }^{\mathrm{b}}$ Includes the following brands: Nuoc Mam Nhi, Purfina Patis, Tentay Patis, Lucky, Mega Chef, Essential, Squid Brand.

${ }^{c}$ Individual sauce ingredients comprise various combinations of listed ingredients within tier.

\subsection{Statistical Analysis}

The data were tested for normality using a Shapiro-Wilks test. Outliers were identified and removed when appropriate. The results were analyzed for variance using multivariate ANOVA for normal data and Kruskal-Wallis test for non-normal data. Tukey's honestly significant difference (HSD) post hoc test was used to identify statistically significant $(p<0.05)$ differences among treatments after testing for variance in R Version 3.6.1 (R Studio, Boston, MA, USA).

\section{Results}

\subsection{Commercial Fish Sauces}

In comparing the ingredients of commercial sauces currently available in the marketplace, two distinct groups emerged. One of these (Tier 1) contained only minimal ingredients characteristic of a traditionally fermented fish sauce, while a second (Tier 2) contained various additional, "non-traditional" ingredients. In order to allow for the calculation of mean values for comparison to lab-fermented sauce, the commercial sauces were separated into two categories (Table 1).

Between the two tiers of commercial product, there were apparent differences in water activity, TVBN, and amine nitrogen. These differences were statistically significant and suggest that the use of traditional vs. non-traditional ingredients results in a different sauce. 
Tier 2 sauces had a significantly higher water activity, and significantly lower TVBN and amine nitrogen contents than tier 1 sauces.

The commercial sauces made from traditional ingredients-i.e., fish, salt, and sometimes sugar and water-were selected as a more appropriate target for the experimental product. They were compared to the lab-fermented crab sauces to identify properties of significant difference. The lab fermented crab samples had a significantly higher $\mathrm{pH}$ at all salt levels. The water activity of the $100 \mathrm{mg} \mathrm{g}^{-1}$ salt lab-fermented sample $(0.857 \pm 0.004)$ was also significantly higher than the mean of the tier 1 commercial samples $(0.74 \pm 0.01)$, but no difference between higher salt and commercial formulations was detected.

\subsection{Microbial Activity}

Yeast and mold levels in general (Table 2) were low in all treatments and did not have any significant differences due to treatment or time during the fermentation.

Table 2. Fungal population in lab fermented crab sauces.

\begin{tabular}{|c|c|c|c|}
\hline Time (Day) & $100 \mathrm{mg} \mathrm{g}^{-1}$ Salt $\left(\log \mathrm{CFUg}^{-1}\right)$ & $200 \mathrm{mg} \mathrm{g}^{-1}$ Salt $\left(\log \mathrm{CFUg}^{-1}\right)$ & $300 \mathrm{mg} \mathrm{g}^{-1}$ Salt $\left(\log \mathrm{CFUg}^{-1}\right)$ \\
\hline 60 & $2.5 \pm 0.7$ & $2.7 \pm 0.5$ & $2.5 \pm 0.8$ \\
\hline 90 & $2.1 \pm 0.1$ & $2.0 \pm 0.0$ & $2.0 \pm 0.0$ \\
\hline 120 & $2.2 \pm 0.1$ & $2.2 \pm 0.2$ & $2.5 \pm 0.4$ \\
\hline
\end{tabular}

Data are expressed as mean \pm standard deviation $(n=3)$, no statistical differences identified.

No distinct trends were found in the levels of any of the microorganisms of interest (total count, proteolytic bacteria, fungi). Based on the model level effects, an increase in salt content negatively affected the proteolytic bacteria (Figure 1) population. However, the only significant difference among treatments was between $100 \mathrm{mg} \mathrm{g}^{-1}$ and $300 \mathrm{mg} \mathrm{g}^{-1}$ salt samples (6.6 $\pm 0.3 \log C F U g^{-1}$ and $3.5 \pm 0.4 \log C F U g^{-1}$ respectively) on day 120 .

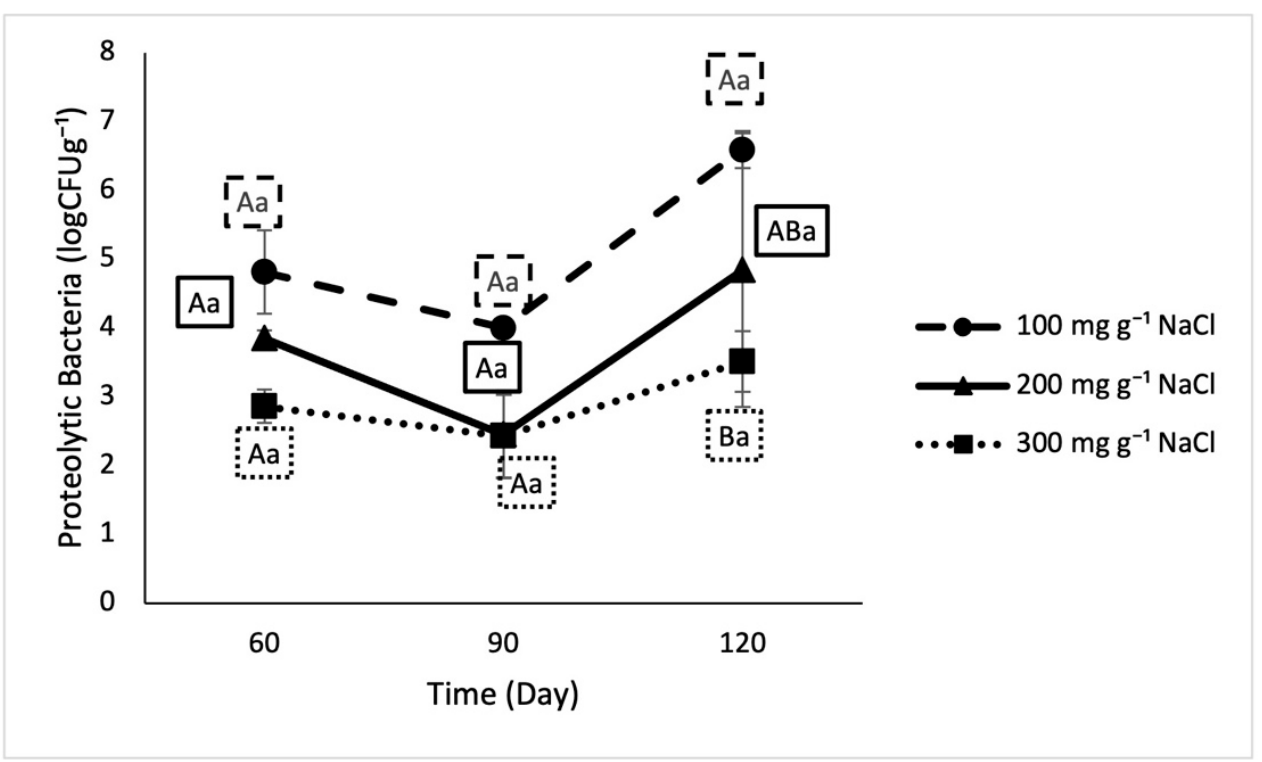

Figure 1. Proteolytic bacterial population in lab fermented crab sauce samples over time. Uppercase letters designate significant differences among treatments on individual testing dates. Lowercase letters designate significant differences within treatment across time $(n=3)$.

Both longer fermentation time and higher salt content had significant model level effects on TPC (Figure 2) that resulted in increased plate count. 


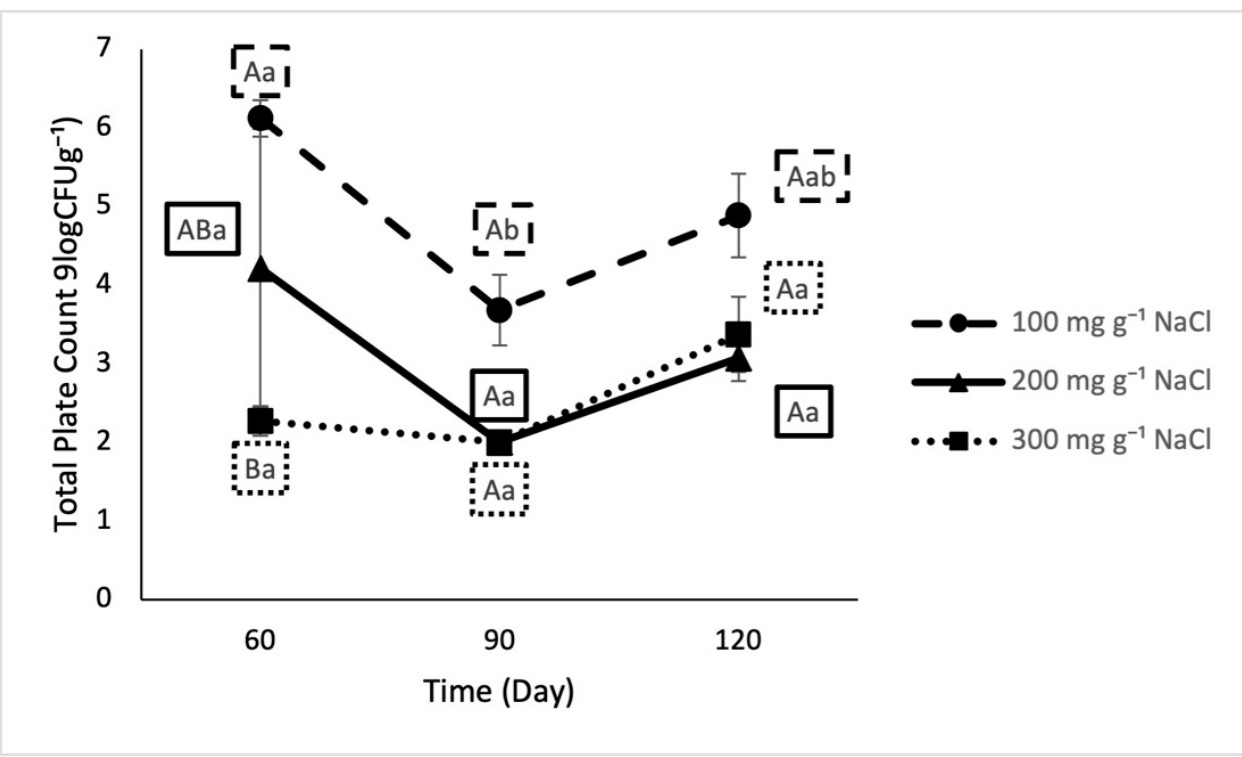

Figure 2. Total plate count in lab fermented crab sauce samples over time. Uppercase letters designate significant differences among treatments on individual testing dates. Lowercase letters designate significant differences within treatment across time $(n=3)$.

\subsection{TVBN and Amine N}

In our analysis, TVBN did not increase over time, but crab sauce formulated with

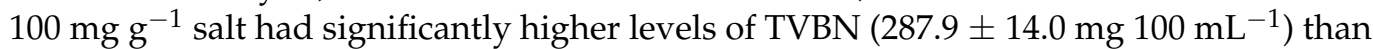

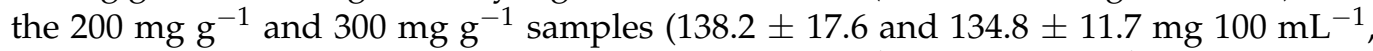
respectively) at all time points (Figure 3). The $200 \mathrm{mg} \mathrm{g}^{-1}$ and $300 \mathrm{mg} \mathrm{g}^{-1}$ salt treatments were statistically indistinguishable from each other regardless of time.

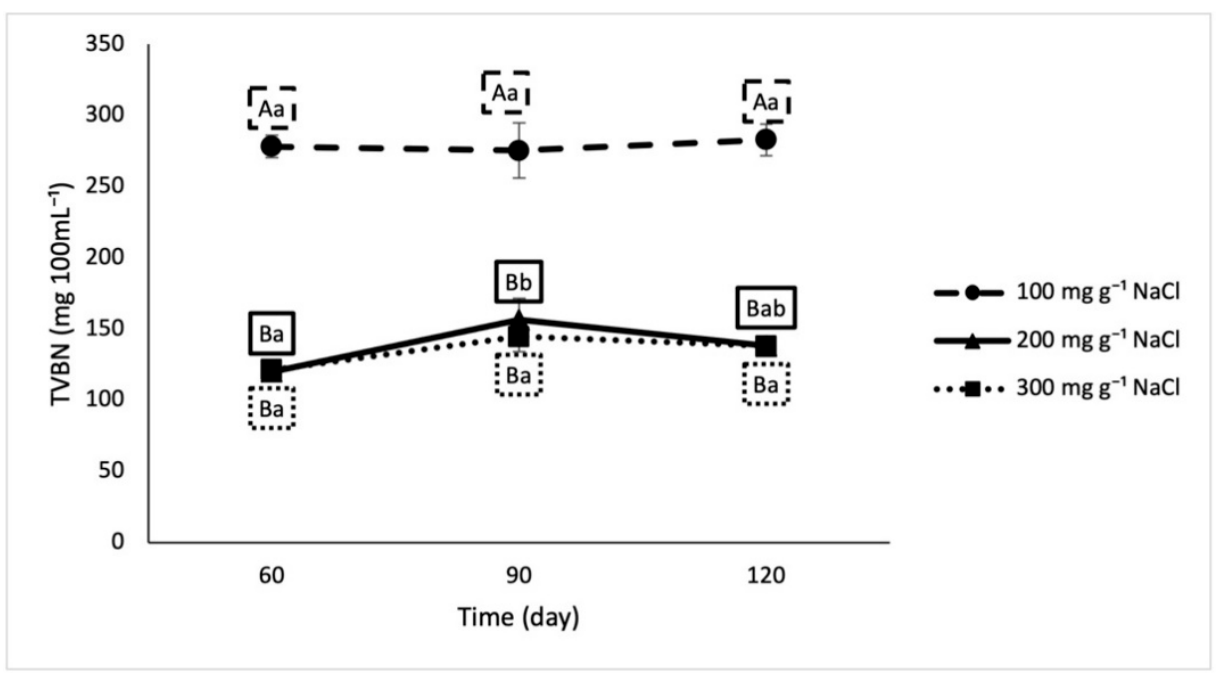

Figure 3. Total volatile basic nitrogen in lab fermented crab sauce samples over time. Uppercase letters designate significant differences between treatments on individual testing dates. Lowercase letters designate significant differences within treatment across time $(n=3)$.

Although there were significant differences in amine nitrogen levels among treatments, with the $100 \mathrm{mg} \mathrm{g}^{-1}$ salt treatment having significantly higher amine nitrogen

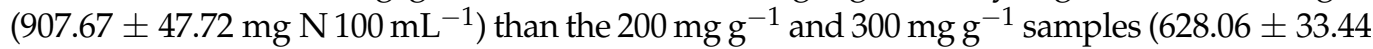
and $581.00 \pm 39.92 \mathrm{mgN} 100 \mathrm{~mL}^{-1}$, respectively), the amine nitrogen levels did not increase over time in any treatment (Table 3 ). 
Table 3. Amine nitrogen in lab fermented crab sauce samples.

\begin{tabular}{|c|c|c|c|}
\hline Time (Day) & $100 \mathrm{mg} \mathrm{g}^{-1}$ Salt (mgN $\left.100 \mathrm{~mL}^{-1}\right)$ & $200 \mathrm{mg} \mathrm{g}^{-1}$ Salt (mgN $\left.100 \mathrm{~mL}^{-1}\right)$ & $300 \mathrm{mg} \mathrm{g}^{-1}$ Salt $\left(\mathrm{mgN} 100 \mathrm{~mL}^{-1}\right)$ \\
\hline 60 & $884.3 \pm 56.5 \mathrm{a}$ & $581.0 \pm 17.4_{\mathrm{b}}$ & $539.0 \pm 9.9_{b}$ \\
\hline 90 & $864.5 \pm 168.5 \mathrm{a}$ & $655.7 \pm 1.6_{\mathrm{b}}$ & $569.33 \pm 46.2_{b}$ \\
\hline 120 & $974.2 \pm 24.6 \mathrm{a}$ & $647.5 \pm 32.2_{b}$ & $634.7 \pm 10.0_{\mathrm{b}}$ \\
\hline
\end{tabular}

Lowercase letters designate significant differences between treatments on individual testing dates. Data are expressed as mean \pm standard deviation $(n=3)$.

\section{4. $p H$, Water Activity, and Moisture Content}

Differences in $\mathrm{pH}$ were driven by time (Figure 4). From day 90 to 120, the $\mathrm{pH}$ of the higher salt samples did not change, but the mean $\mathrm{pH}$ of the $100 \mathrm{mg} \mathrm{g}^{-1}$ salt sample significantly decreased.

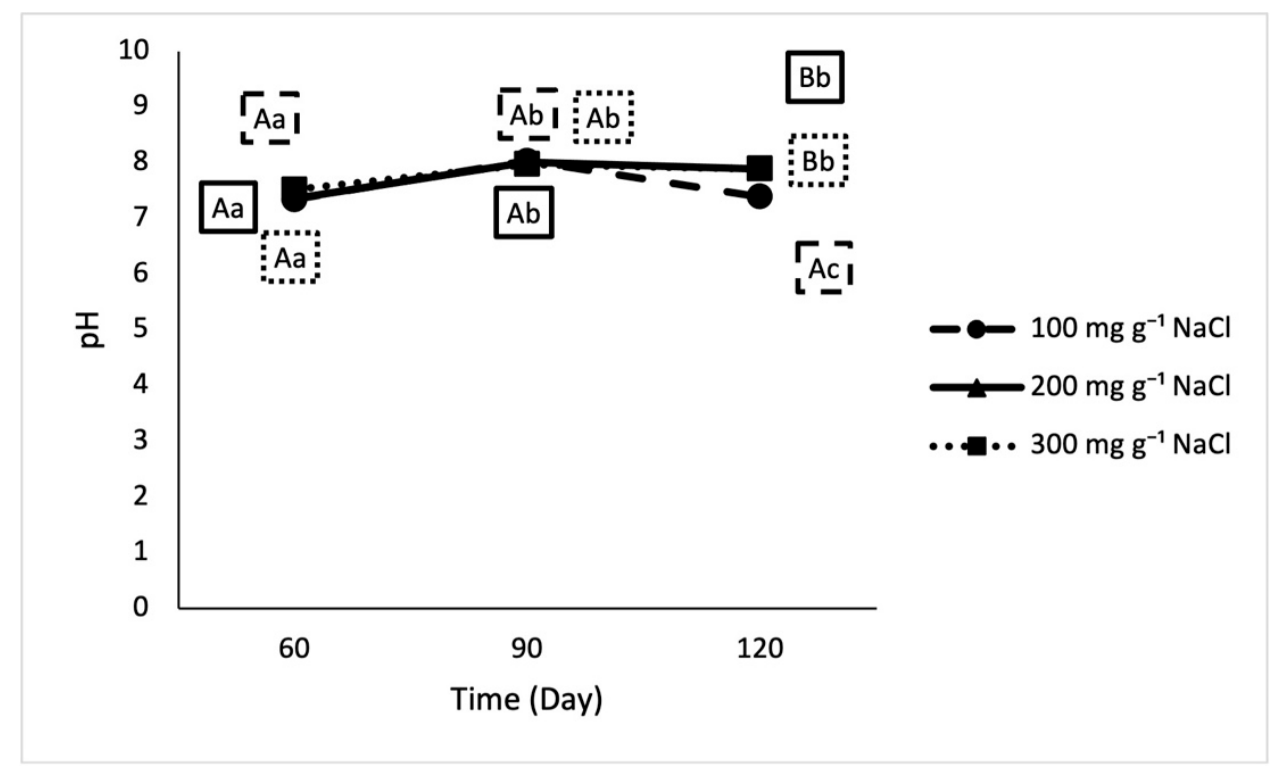

Figure 4. $\mathrm{pH}$ in lab fermented crab sauce samples over time. Uppercase letters designate significant differences between treatments on individual testing dates. Lowercase letters designate significant differences within treatment across time $(n=3)$.

Crab sauces made with $200 \mathrm{mg} \mathrm{g}^{-1}(0.748 \pm 0.005)$ and $300 \mathrm{mg} \mathrm{g}^{-1}(0.744 \pm 0.004)$ salt had significantly $(p<0.05)$ lower water activities than those prepared with $100 \mathrm{mg} \mathrm{g}^{-1}$ salt $(0.861 \pm 0.006)$ at all time points (Table 4$)$, as expected.

Table 4. Water activity in lab fermented crab sauce samples.

\begin{tabular}{|c|c|c|c|}
\hline Time (Day) & $100 \mathrm{mg} \mathrm{g}^{-1}$ Salt & $200 \mathrm{mg} \mathrm{g}^{-1}$ Salt & $300 \mathrm{mg} \mathrm{g}^{-1}$ Salt \\
\hline 60 & $0.866 \pm 0.004 \mathrm{a}$ & $0.744 \pm 0.001_{\mathrm{b}}$ & $0.741 \pm 0.001_{b}$ \\
\hline 90 & $0.862 \pm 0.005 \mathrm{a}$ & $0.751 \pm 0.007 \mathrm{~b}$ & $0.744 \pm 0.003 \mathrm{~b}$ \\
\hline 120 & $0.857 \pm 0.004 \mathrm{a}$ & $0.749 \pm 0.002 \mathrm{~b}$ & $0.748 \pm 0.002 \mathrm{~b}$ \\
\hline
\end{tabular}

Lowercase letters designate significant differences between treatments on individual testing dates. Data are expressed as mean \pm standard deviation $(n=3)$.

Similar to water activity, the moisture content (Table 5) of samples made with $200 \mathrm{mg} \mathrm{g}^{-1}$ $(66.61 \pm 2.13 \%)$ and $300 \mathrm{mg} \mathrm{g}^{-1}$ of salt $(68.32 \pm 0.43)$ was significantly lower than those prepared with $100 \mathrm{mg} \mathrm{g}^{-1}$ salt $(74.52 \pm 0.95 \%)$ at all time points. 
Table 5. Moisture in lab fermented crab sauce samples.

\begin{tabular}{|c|c|c|c|}
\hline Time (Day) & $100 \mathrm{mg} \mathrm{g}^{-1}$ Salt (\%) & $200 \mathrm{mg} \mathrm{g}^{-1}$ Salt (\%) & $300 \mathrm{mg} \mathrm{g}^{-1}$ Salt (\%) \\
\hline 60 & $75.8 \pm 0.4_{\mathrm{a}}$ & $67.5 \pm 0.3_{b}$ & $68.6 \pm 0.6_{b}$ \\
\hline 90 & $73.8 \pm 2.8 \mathrm{a}$ & $68.7 \pm 0.7_{b}$ & $68.7 \pm 2.8_{b}$ \\
\hline 120 & $73.9 \pm 1.9 \mathrm{a}$ & $63.7 \pm 9.0_{\mathrm{b}}$ & $67.7 \pm 0.4_{b}$ \\
\hline
\end{tabular}

Lowercase letters designate significant differences between treatments on individual testing dates. Data are expressed as mean \pm standard deviation $(n=3)$.

\subsection{Non-Enzymatic Browning}

Non-enzymatic browning is the development of the brown color of the sauce caused by reactions such as the Maillard reaction. The Maillard reaction primarily involves the reaction of reducing sugars, oxidation products, and free amino acids [8]. The degree of non-enzymatic browning (Figure 5) of samples fermented with $200 \mathrm{mg} \mathrm{g}^{-1}$ and $300 \mathrm{mg} \mathrm{g}^{-1}$ salt was significantly higher than that observed in the $100 \mathrm{mg} \mathrm{g}^{-1}$ samples on days 60 and 90 , but results were not significantly different due to treatment on day 120 . The nonenzymatic browning on day $120(0.237 \pm 0.00)$ was found not to be significantly different from the Tier 1 commercial samples at any of the salt levels.

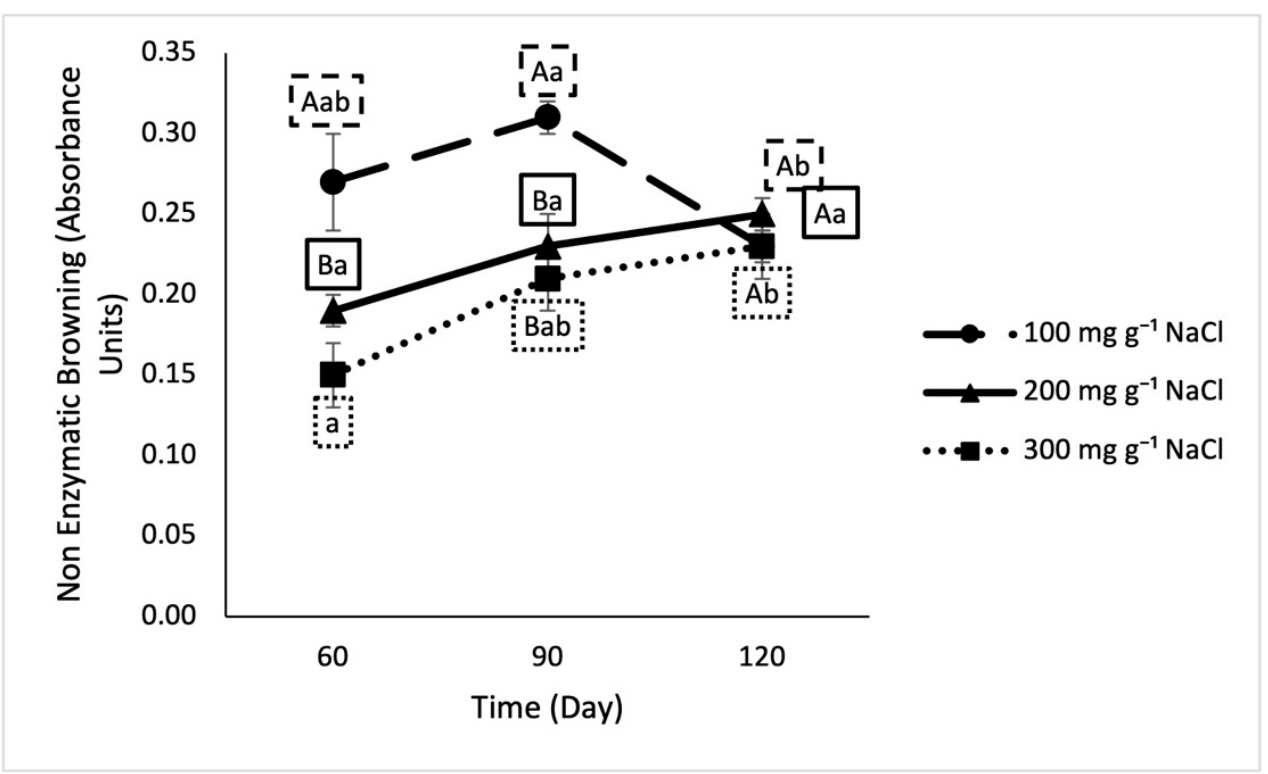

Figure 5. Non-enzymatic browning in lab fermented crab sauce samples over time. Uppercase letters designate significant differences between treatments on individual testing dates. Lowercase letters designate significant differences within treatment across time $(n=3)$.

\subsection{Biogenic Amines}

There was no significant effect on the biogenic amine concentration (Table 6) from time or salinity. Data are expressed as averages among time and salinity. Cadaverine and tyramine were not identified in any of the crab sauces.

Table 6. Biogenic Amine Concentration of Lab Fermented Crab Sauce Samples.

\begin{tabular}{cc}
\hline Biogenic Amine & Average Concentration $\left(\mathbf{m g} \mathbf{1 0 0} \mathbf{~ m L}^{-\mathbf{1}}\right)$ \\
\hline Histamine & $6.01 \pm 1.54$ \\
Putrescine & $3.50 \pm 1.69$ \\
Agmatine & $4.34 \pm 5.07$ \\
\hline
\end{tabular}

Data are expressed as mean \pm standard deviation $(n=27)$, not statistical differences detected. 


\section{Discussion}

Fish sauce is traditionally made through spontaneous fermentation. During spontaneous fish sauce fermentation, proteolytic enzymes break down fish flesh. This proteolysis is induced by endogenous proteases found in the muscles and the digestive tracts of the fish/crab and the activity of natural microbiota. The speed at which this degradation occurs depends on a number of factors including the amount of salt in the formulation and the incubation temperature of the raw materials. The catabolism of proteins yields a varied assortment of nitrogenous compounds responsible for the aroma and flavor of traditional fish sauce [25]. This spontaneous fermentation was the method used to make a fermented condiment from Carcinus maenas in this study. The formulations studied consisted of crab and $100 \mathrm{mg} \mathrm{g}^{-1}, 200 \mathrm{mg} \mathrm{g}^{-1}$, or $300 \mathrm{mg} \mathrm{g}^{-1}$ salt.

In traditional fish sauce fermentation, proteolytic bacteria are expected to be present at populations of almost $4.0 \log \mathrm{CFUg}^{-1}$ after 4 months $[19,26]$. The proteolytic bacterial population in this study ranged from 2.4-3.5 $\log \mathrm{CFU} \mathrm{g}^{-1}$ after 120 days of fermentation. As the fermentation progresses, the enzymes produced by these bacteria catabolize the proteins in the raw material, resulting in the formation of peptides and amino acids, measured in this study as amine nitrogen. Total volatile base nitrogen also increases with time, giving rise to odiferous compounds that drive the use of this metric as an indicator of spoilage in fish [27]. Because they result from the breakdown of proteins, which characterizes the process of fish sauce fermentation, both of these indices could be expected to increase with increasing fermentation duration (to almost $2400 \mathrm{mg} 100 \mathrm{~mL}^{-1}$ and $600 \mathrm{mg} 100 \mathrm{~mL}^{-1}$, respectively) [19,28]. That was not, however, observed in our study. Data in this study suggests that the majority of protein catabolism occurred in the very early stages of the fermentation.

In some instances, depending on the microbiota present in the system, amino acids are decarboxylated to release biogenic amines, such as histamine. Biogenic amine content can be an indicator of product quality and aids in determining acceptability of a commercial sample. A high histamine content specifically can cause scombroid poisoning, which causes rash, swelling, and vomiting [28]. As a result, in the United States, fish sauce cannot legally contain more than $50 \mathrm{mg} 100 \mathrm{~mL}^{-1}$ of histamine [29]. Histamine levels were low in experimental product, which could suggest that the native flora of Carcinus maenas is largely non-histamine producing. Agmatine was not recovered from most commercial samples but was frequently identified in lab fermented sauces, likely due to the difference of arginine content in the starting material. None of the lab fermented samples or commercial samples had a histamine concentration above the legal limit.

Water in foods drives a number of degradative processes. Water activity measures the amount of free water available for bacterial growth [30]. Most pathogenic bacteria are unable to grow at a water activity below 0.9 [31], indicating that vegetative pathogens are unlikely to pose significant food safety concerns for this fermented crab product, particularly in the higher salt formulations, which both had water activity values well below 0.8 .

There is very little information in the literature regarding the sensory aspects driving acceptability of fermented fish sauces. As a result of this fact, we chose to complete a small scale survey of commercial products in order to orient the experimental crab sauce in comparison to potential physicochemical targets. The resulting fermented crab condiment looked and smelled similar to the commercial fish sauces in that it was a dark brown color and smelled like fermented seafood. The $\mathrm{pH}$ was higher in all lab samples than the commercially available samples, most likely due to the higher levels of lactic acid bacterial population associated with fish sauce fermentation [17]. There were no differences between the lab and commercial samples in amine nitrogen content, which shows that the degree of proteolysis that occurred in the lab samples was comparable to the commercial samples. Comparable levels of browning suggest that the color of the experimental crab sauce has the potential to meet current consumer expectations. Levels of TVBN and moisture (in all salt formulas) were also similar to commercial product. However, better characterization 
of the first 60 days of fermentation is warranted. Likewise, consumer acceptability testing is needed in order to assure the palatability of a green crab sauce. Additional investigation should also assess whether the process could be accelerated or consumer appeal could be increased by modification of formula or process alterations.

\section{Conclusions}

The concept of creating a fermented condiment from Carcinus maenas was proven to be a feasible opportunity. The experimental crab sauce product was comparable in many respects to currently available commercial fish sauce products. The optimization of the product and process, as well as consumer sensory evaluation, are called for to ensure the market potential of such a product. The establishment of an economically feasible use for green crabs unsuitable for the high value softshell market will be a key accomplishment in facilitating the development of a viable U.S. fishery for this invasive species and realizing the associated ecological benefits of controlling its population.

Author Contributions: Conceptualization, D.I.S. and J.J.P.; methodology, all authors; formal analysis, D.M.G.; data curation, all authors; writing —original draft preparation, D.M.G.; writing—review and editing, J.J.P., D.I.S., and L.B.P.; visualization, D.M.G.; supervision, D.I.S. and J.J.P.; funding acquisition, D.I.S. and J.J.P. All authors have read and agreed to the published version of the manuscript.

Funding: This work was supported by the Maine Food and Agriculture Center and the USDA National Institute of Food and Agriculture, Hatch Project Number ME0-21915 through the Maine Agricultural and Forest Experiment Station. Experiment Station Publication Number 3796.

Data Availability Statement: Data available upon request from corresponding author.

Acknowledgments: We would like to acknowledge Rosanna Woodruff for processing the crabs and conducting laboratory analyses as well as Marissa McMahan for providing the crabs.

Conflicts of Interest: The authors declare no conflict of interest. The funders had no role in the design of the study; in the collection, analyses, or interpretation of data; in the writing of the manuscript, or in the decision to publish results.

\section{References}

1. St-Hilaire, S.; Krause, J.; Wight, K.; Poirier, L.; Singh, K. Break-even analysis for a green crab fishery in PEI, Canada. Manag. Biol. Invasions 2016, 7, 297-303. [CrossRef]

2. Lovell, S.; Besedin, E.; Grosholz, E. Modeling economic impacts of the European green crab. Sel. Pap. Prep. Present. Am. Agric. Econ. Assoc. Annu. Meet. 2007, 2339. [CrossRef]

3. Malyshev, A.; Quijón, P.A. Disruption of essential habitat by a coastal invader: New evidence of the effects of green crabs on eelgrass beds. ICES J. Mar. Sci. 2011, 68, 1852-1856. [CrossRef]

4. Heck, K.L.; Hays, G.; Orth, R.J. Critical evaluation of the nursery role hypothesis for seagrass meadows. Mar. Ecol. Prog. Ser. 2003, 253, 123-136. [CrossRef]

5. Williams, P.J.; Floyd, T.A.; Rossong, M.A. Agonistic interactions between invasive green crabs, Carcinus maenas (Linnaeus), and sub-adult American lobsters, Homarus americanus (Milne Edwards). J. Exp. Mar. Biol. Ecol. 2006, 329, 66-74. [CrossRef]

6. Department of Marine Resources. Available online: https://www.maine.gov/dmr/science-research/species/invasives/ greencrabs/index.html (accessed on 2 February 2021).

7. Teigiserova, D.A.; Hamelin, L.; Thomsen, M. Towards transparent valorization of food surplus, waste and loss: Clarifying definitions, food waste hierarchy, and role in the circular economy. Sci. Total Environ. 2020, 706, 136033. [CrossRef] [PubMed]

8. Lopetcharat, K.; Choi, Y.J.; Park, J.W.; Daeschel, M.A. Fish sauce products and manufacturing: A review. Food Rev. Int. 2001, 17, 65-88. [CrossRef]

9. Martínez-Álvarez, O.; López-Cabellero, M.E.; Gómez-Guillén, M.C.; Montero, P. Traditional fermented foods. Biotechnol. Bioeng. $1967,9,177-202$.

10. El Sheikha, A.F; Montet, D. Fermented fish and fish products: Snapshots on culture and health. In Microorganisms and Fermentation of Traditional Foods, 1st ed.; Ray, R.C., Didier, M., Eds.; CRC Press: Boca Raton, FL, USA, 2014; Volume 1, pp. 188-222.

11. America's Test Kitchen. Available online: https://www.americastestkitchen.com/taste_tests/1625-fish-sauce (accessed on 2 February 2021).

12. Pariona-Velarde, D.; Maza-Ramírez, S.; Ayala Galdos, M. Nutritional characteristics of a Peruvian anchovy (Engraulis ringens) protein concentrate. J. Aquat. Food Prod. Technol. 2020, 29, 707-719. [CrossRef]

13. Achi, O.; Anokwuru, I.; Ogbo, F. Microbiological and chemical changes during fermentation of crabs for ogiri-nsiko production. Am. J. Food Technol. 2007, 2, 301-306. [CrossRef] 
14. Brillantes, S.; Paknoi, S.; Totakien, A. Histamine formation in fish sauce production. J. Food Sci. 2002, 67, 2090-2094. [CrossRef]

15. Kopermsub, P.; Yunchalard, S. Identification of lactic acid bacteria associated with the production of plaa-som, a traditional fermented fish product of Thailand. Int. J. Food Microbiol. 2010, 138, 200-204. [CrossRef] [PubMed]

16. Lee, Y.C.; Kung, H.F.; Huang, C.Y.; Huang, T.C.; Tsai, Y.H. Reduction of histamine and biogenic amines during salted fish fermentation by Bacillus polymyxa as a starter culture. J. Food Drug Anal. 2016, 24, 157-163. [CrossRef]

17. Saithong, P.; Panthavee, W.; Boonyaratanakornkit, M.; Sikkhamondhol, C. Use of a starter culture of lactic acid bacteria in plaa-som, a Thai fermented fish. J. Biosci. Bioeng. 2010, 110, 553-557. [CrossRef] [PubMed]

18. Skonberg, D.I.; Perkins, B.L. Nutrient composition of green crab (Carcinus maenus) leg meat and claw meat. Food Chem. 2002, 77, 401-404. [CrossRef]

19. Zaman, M.Z.; Abu Bakar, F.; Jinap, S.; Bakar, J. Novel starter cultures to inhibit biogenic amines accumulation during fish sauce fermentation. Int. J. Food Microbiol. 2011, 145, 84-91. [CrossRef] [PubMed]

20. Botta, J.R.; Lauder, J.T.; Jewer, M.A. Effect of methodology on total volatile basic nitrogen (TVB-N) determination as an index of quality of fresh atlantic cod (Gadus morhua). J. Food Sci. 1984, 49, 734-736. [CrossRef]

21. Zhou, X.; Qiu, M.; Zhao, D.; Lu, F.; Ding, Y. Inhibitory effects of spices on biogenic amine accumulation during fish sauce fermentation. J. Food Sci. 2016, 81, M913-M920. [CrossRef]

22. Joung, B.C.; Min, J.G. Changes in postfermentation quality during the distribution process of anchovy (Engraulis japonicus) fish sauce. J. Food Prot. 2018, 81, 969-976. [CrossRef]

23. AOAC International. AOAC Official Method 934.01. In Official Methods of Analysis of AOAC International, 18th ed.; AOAC International: Rockville, MD, USA, 2005.

24. Zhao, J.; Jiang, Q.; Xu, Y.; Xia, W. Effect of mixed kojis on physiochemical and sensory properties of rapid-fermented fish sauce made with freshwater fish by-products. Int. J. Food Sci. Technol. 2017, 52, 2088-2096. [CrossRef]

25. Zheng, B.; Liu, Y.; He, X.; Hu, S.; Li, S.; Chen, M.; Jiang, W. Quality improvement on half-fin anchovy (Setipinna taty) fish sauce by Psychrobacter sp. SP-1 fermentation. J. Sci. Food Agric. 2017, 97, 4484-4493. [CrossRef] [PubMed]

26. Yuen, S.K.; Yee, C.F.; Anton, A. Microbiological Characterization of an Indigenous Budu Malaysian Fish Sauce. Borneo Sci. 2009, 24, 25-35.

27. Pacquit, A.; Lau, K.T.; McLaughlin, H.; Frisby, J.; Quilty, B.; Diamond, D. Development of a volatile amine sensor for the monitoring of fish spoilage. Talant 2006, 69, 515-520. [CrossRef] [PubMed]

28. Wang, Y.; Li, C.; Li, L.; Yang, X.; Wu, Y.; Zhao, Y.; Wei, Y. Effect of bacterial community and free amino acids on the content of biogenic amines during fermentation of yu-lu, a Chinese fermented fish sauce. J. Aquat. Food Prod. Technol. 2018, 27, 496-507. [CrossRef]

29. Food and Drug Administration. Chapter 7: Scombrotoxin (histamine) formation. In Fish and Fishery Products Hazard and Control Guidance, 4th ed.; Department of Health and Human Services: Washington, DC, USA, 2019; pp. 113-151.

30. Brady, J.W. Introductory Food Chemistry, 1st ed.; Cornell University: New York, NY, USA, 2013; pp. 159-172.

31. Fellows, P. Food Processing Technology, First, Technology Guide: Principles-Applications—Trends, 1st ed.; Woodhead Publishing Limited: Cambridge, UK, 2000. 